\title{
Scientific Report: Second Edition of the International Conference "Medieval Europe in Motion"
}

\section{Alicia Miguélez Cavero}

\section{(2) OpenEdition}

\section{Journals}

Edição electrónica

URL: http://journals.openedition.org/medievalista/1156

DOI: 10.4000/medievalista.1156

ISSN: 1646-740X

Editora

Instituto de Estudos Medievais - FCSH-UNL

\section{Refêrencia eletrónica}

Alicia Miguélez Cavero, "Scientific Report: Second Edition of the International Conference "Medieval Europe in Motion" ", Medievalista [Online], 18 | 2015, posto online no dia 01 junho 2015, consultado o 23 setembro 2020. URL : http://journals.openedition.org/medievalista/1156 ; DOI : https://doi.org/ 10.4000/medievalista.1156

\section{(c) (7) (5)}

Mediavalista está licenciado com uma Licença Creative Commons - Atribuição-NãoComercial 4.0 Internacional. 
Título: Scientific Report: Second Edition of the International Conference "Medieval Europe in Motion”

Autor(es): Alícia Miguélez Cavero

Universidade: Universidade Nova de Lisboa

Faculdade e Departamento / Unidade de Investigação: Faculdade de Ciências Sociais e Humana / Instituto de Estudos Medievais

Código Postal: 1069-061

Cidade: Lisboa

País: Portugal

Contacto: amiguelez@fcsh.unl.pt

Fonte: Medievalista [Em linha]. Direc. José Mattoso. Lisboa: IEM.

Disponível em:

http://www2.fcsh.unl.pt/iem/medievalista/MEDIEVALISTA18/cavero1814.html

ISSN: 1646-740X

Data do texto: Abril de 2015 


\title{
Scientific Report : Second Edition of the International Conference "Medieval Europe in Motion"
}

\author{
Alícia Miguélez Cavero
}

The Second Edition of the International Conference "Medieval Europe in Motion" took place in Lisbon in April 4-6, 2015. It aimed to follow up the initiative "Medieval Europe in Motion: the circulation of artists, images, patterns and ideas, from the Mediterranean to the Atlantic coast", held in Lisbon in 2013 and organized by the Institute for Medieval Studies of the Nova University Lisbon.

With the aim of creating academic, scientific and organizational synergies, this second edition was organized in collaboration with two other international institutions, the research group "Tardogótico" of the University of Cantabria and the Institute for Medieval Studies of the University of León. The organizing committee, made up by Dr. Fernando Villaseñor and Dr. Alicia Miguélez, counted with the advise of a large honour and scientific committees and the generous financial support of several public and private institutions: Calouste Gulbenkian Foundation, National Library of Portugal, the Portuguese Foundation for Science and Technology, CM Editores, The Association for Spanish and Portuguese Historical Studies, El Corte Inglês and Hotel Sana Executive.

The main scientific goal of the event, as it was in the previous conference, was to analyze the phenomenon of circulation, motion and mobility of people, forms and ideas during the Middle Ages. This time, however, the kind of works under consideration was Illuminated Manuscripts of the Iberian Peninsula. This three-day Conference aimed thus to conduct a critical and constructive revision of research on Iberian Book Illumination 
in the Middle Ages, proposing new questions to be discussed. The works to be surveyed were manuscripts of all kinds, both in its form and content.

The three-day conference, the first of which took place at the Calouste Gulbenkian Foundation and the other two in the National Library of Portugal, was organized in six sessions, each of them with two keynote presentations by senior scholars and parallel sessions with papers delivered by junior researchers. The sessions were devoted to the following topics:

\section{1) The phenomenon of mobility in Medieval times:}

Why did it happen? Who travelled? Where did they travel (to)? What reasons motivated the circulation of people? How did mobility influence, stimulate and condition the production of manuscripts?

\section{2) Clients and promoters, both individual and institutional:}

To what extent did their own travels and vital experiences influence their decisions when ordering new works? How did fashion and taste influence the promoters' choices?

\section{3) Material authors:}

How did their itinerant lives influence their creations? To what extent was the production of new works conditioned by the presence of foreign scribes/illuminators in specific geographical contexts? How did they transfer models to new places/media? To what extent were they influenced by the models they saw when passing through other places/contexts and by the tradition they found when arriving at new places?

\section{4) Models:}

The concepts of copy, reinterpretation, reuse and re-elaboration were under discussion, as well as the confluence of several graphic languages in the same work; the influence of old models in later works was also addressed.

\section{5) Image performance:}

Analysis of several concepts regarding the influence of the phenomena of circulation and mobility on the image performance - the agency, efficiency, effectiveness and power of the image, both in Medieval and later times.

Medievalista online № 18| Julho - Dezembro 2015 ๑ IEM - Instituto de Estudos Medievais 3 www2.fcsh.unl.pt/iem/medievalista 


\section{6) Manuscript acquisition:}

Regarding the postproduction process, that is the sale and circulation of already finished works, several matters were approached, such as the artistic market, the existence of a luxury market in Medieval times, and the act of collecting manuscripts both in the Middle Ages and in later periods.

After three days of intense work and scientific exchange among the more than fifty researchers gathered from various countries of Europe, America and Asia, presentations and papers made possible to reach a number of key conclusions and enabled the opening of new lines of work that will be decisive for the future of scientific research on the medieval illuminated manuscripts in the Iberian Peninsula.

Firstly, it was proved once again the intense movement of people, ideas and models, both across Medieval Europe and the Iberian Peninsula through pilgrimages and journeys of various kinds. Researchers stressed the importance of the role played by clients and promoters and how their own journeys, personal motivations and beliefs were crucial when fostering the creation of new works. The importance of patron's connections across geographical and political boundaries and the effect that these could have on their taste was emphasized, pinpointing the choices that affected content, style and function of illuminated manuscripts.

Scholars working on the materiality of manuscripts and the role played by copyists and illuminators proved the importance of carrying out interdisciplinary studies, namely in conjunction with chemists, for a better understanding of the use of materials, colors and pigments in medieval scriptoria. This scientific exchange between art historians and chemists was no doubt one of the greatest achievements of this Conference.

Another major innovation presented at the conference was the study of the use and reuse of Flemish illuminated manuscripts in Late Medieval Castile and the - until recently little studied phenomenon of hybridization between Iberian and Flemish copyists and illuminators. It was shown how it is possible to find manuscripts copied by Iberian scribes but illuminated by Flemish artists; Flemish manuscripts whose illumination was

Medievalista online $N^{\circ} 18 \mid$ Julho - Dezembro 2015 ๑ IEM - Instituto de Estudos Medievais 4 www2.fcsh.unl.pt/iem/medievalista 
completed in Castile; and imported loose miniatures that were used to complete Castilian codices.

Regarding the circulation of models, scholars discussed concepts such as archetype, variation and mutation. News about the importance of the liturgical use for Beatus manuscripts was presented, as well as it was highlighted the crucial role played by the Iberian Peninsula in transmitting animal fables of immense popularity in the Islamic World to Northern Europe.

Researchers working on the image performance showed, on their part, how images included in medieval manuscripts were not immutable, but acted developing an authentic performance, in the term's most modern sense. They were images intended to be in continuous interaction with the reader and the viewer.

Finally, scholars presenting research on the process of manuscripts acquisition showed fascinating approaches of the circulation of Medieval Illuminated books to and from the Iberian Peninsula, both in Medieval and later times. Scholars managed to trace Iberian manuscripts itineraries, which reached such remote places as Yemen, a fact that even lead to suggest a kind of early protoglobalization context. On the other hand, the papers also proved the existence of a luxury market for the acquisition of medieval manuscripts within the Iberian Peninsula in Modern times, private clients thus acquiring manuscripts produced in other European territories.

As can be inferred from the major novelties mentioned above, this International Conference seems to have been a great milestone in what research on Medieval Illuminated Manuscripts is concerned. It also helped to bring together senior and junior researchers, as well as scholars working at Iberian institutions and universities with those established in non-Iberian places. The main goal from now onwards, will be to follow up and work the new scientific research lines the conference has helped to open.

For further info.: http://medievaleuropeinmotion2015.weebly.com 


\section{COMO CITAR ESTE ARTIGO}

\section{Referência electrónica:}

MIGUÉLEZ CAVERO Alícia - "Scientific Report: Second Edition of the International Conference "Medieval Europe in Motion".

Medievalista [Em linha]. No 18 (Julho - Dezembro 2015). [Consultado dd.mm.aaaa].

Disponível em

http://www2.fcsh.unl.pt/iem/medievalista/MEDIEVALISTA18/cavero1814.html ISSN 1646-740X.

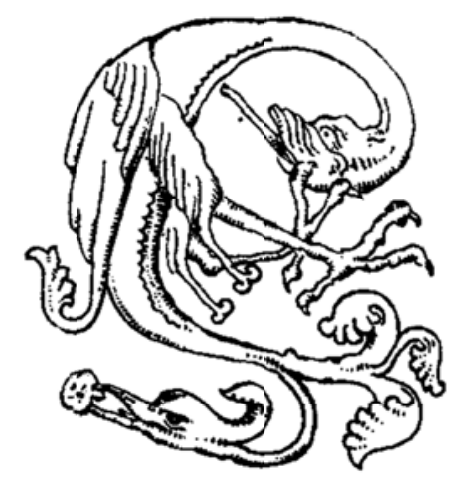

